\title{
The Role of the Sacraments of Christian Initiation in Preparing the Faithful for Marriage and Family Life
}

Today, many of the faithful who are preparing for marriage and family life have not received sufficient formation at home-a formation that would ensure that they receive the sacraments of Christian initiation. The sacraments of Baptism, Confirmation, and the Eucharist graft man onto Christ and enable him to become both a new creature and a member of the Catholic Church. The role of the Church, therefore, is to convey to the faithful the relationship that exists between the sacrament of Marriage, for which they are preparing, and the sacraments of Christian initiation. These sacraments are an integral part of the sacramental economy by which faithful and practicing Christians live. In seeking the proper way to grow in their future life together, engaged couples must perceive the deep connection between married life and the sacraments of initiation. Frequently, however, members of the faithful have received the sacraments of Christian initiation but have not truly encountered Christ in their lives. In this case, such individuals neither understand what the Christian community is, nor do they feel like they are full members of the Church to which they were introduced by virtue of the sacraments. Therefore, it is necessary to seek solutions to help these individuals create a marital and family life that is permeated by Christ's presence.

Key words: initiation, Christian initiation, Baptism, Confirmation, Eucharist, preparation for marriage and family life.

The sacraments of Christian initiation are not solely liturgical actions. Baptism, Confirmation, and the Eucharist are meant to introduce 
Pastoral theology

initiated Christians into a new reality for the rest of their lives. ${ }^{1}$ Therefore, by participating in the sacraments of Christian initiation, man also celebrates his own spiritual renewal. ${ }^{2}$

Those who are preparing for marriage and family life often have difficulty understanding the meaning and theological message of the sacraments of Christian initiation. For this reason, this article seeks to show the role that the sacraments of Christian initiation play in preparing individuals for marriage and living out these sacraments in their family life. Sacraments such as Confirmation, Baptism, and the Eucharist make up the uniquely salvific experience called "Christian initiation," through which the faithful are grafted onto Christ and thereby become new creatures and members of the Church. ${ }^{3}$

\section{The Sacraments of Christian Initiation}

Christian initiation is useful not only for those who have been inspired by the Holy Spirit and are preparing to receive the sacraments, but also for the entire community of believers in Christ. The specific elements of Christian initiation are important. In Christianity, Christians are initiated into the mystery of God, who entered into history and guides man along the paths of salvation. ${ }^{4}$ By celebrating the death and resurrection of Christ in the sacraments of initiation, the entire community of the faithful gradually witnesses children being initiated

1 Initiation (in Latin, "introduction") is an act that is recognized as a symbolic initiation into a new (higher) state of cultural, social, religious life, or activity. Por. S. Janeczek, Inicjacja, EK VII, col.211; C. Krakowiak, "Inicjacja chrześcijańska," in Leksykon Teologii Pastoralnej, R. Kamiński, W. Przygoda, M. Fiałkowski (eds.), Lublin 2006, pg. 298.

2 The term initiation does not occur in the New Testament. Ideologically, the term is related to an injunction to enter into missionary work. Based on the Acts of the Apostles (2:38-42), initiation into the Christian community comes about through Baptism and preparation for Baptism as well as casting off one's old way of life, making a profession of faith, and entering into the community. C. Krakowiak, Katecheza chrzcielna $w$ Kościele posoborowym, Lublin 2003, pg. 201.

3 See R. Murawski, Wtajemniczenie chrześcijańskie w pierwotnym Kościele, in Funkcja inicjacyjna katechezy w Kościele wspótczesnym, K. Kantowski (ed.), Szczecin 2007, pgs. 33-52.

$4 \quad$ P. Tomasik, Katecheza i inicjacja w ujęciu dokumentów Kościoła, in Funkcja inicjacyjna katechezy w Kościele współczesnym, pg. 83. 
into the depths of God's mysteries. In this way, the faithful experience the celebration of initiation as a kind of secondary catechumenate. ${ }^{5}$

The rites of Christian initiation of adults entail a complex formation process that is theologically rich. At least two parties are involved in this process: the initiators and the initiates. Every person who participates in initiation receives the grace that is passed on to him according to his sacramental and spiritual state. When people are well informed and pay attention to the value of the sacraments of Christian initiation, they have an opportunity to deepen their knowledge and progress in their formation as they enter into preparation for marriage and family life. ${ }^{6}$ The Catechism of the Catholic Church (CCC) teaches that Baptism, Confirmation, and the Eucharist are the sacraments of Christian initiation that "lay the foundation of every Christian life" (1212). Through Baptism and the Eucharist, man is welcomed into the saving mystery of God, and this reality is realized and deepened through Confirmation and the other sacraments. ${ }^{7}$

Baptism is the first sacrament of Christian initiation. Through it, every disciple of Christ enters on the path of faith. Christ instituted this sacrament when he gave his disciples the mandate to: "Go, therefore, and make disciples of all nations, baptizing them in the name of the Father and of the Son, and of the Holy Spirit" (Mt 28:19). In this way, the early Church welcomed new members into its community through Baptism (Acts 8:12, 36; 9:10; 10:44; Romans 6:3). Even at its inception, the Church was aware of the consequences of baptism, which: purifies an individual from sin, sanctifies, imparts the gift of grace, incorporates the neophytes into the community of the People of God, and marks them with the seal of the Holy Spirit. ${ }^{8}$

In the New Testament, Baptism is understood as being immersed into Christ's death and resurrection (Romans 6:3-5). To provide a deeper explanation of the meaning of Baptism, St. Paul made a parallel between Adam and Christ, where Adam represents life in death due to his disobedience to God, while Christ represents life because he introduces man into new life in him. St. Paul teaches that the

$5 \quad$ A. Jastrzębski, Katechumenat jako droga do dojrzałości chrześcijańskiej na kolejnych etapach rozwoju człowieka, "Wrocławski Przegląd Teologiczny," R. 22, no. 2 (2014), pg. 207.

6 J. Szpet, Cel i zadania katechezy, in Dydaktyka katechezy, J. Stala (ed.), Part 1, Tarnow 2004, pg. 45; Ibid, Inicjacyjna funkcja katechezy, "Horyzonty Wiary" 1996, no. 3, pg. 56 .

$7 \quad$ S. Kunka, Sakrament bierzmowania a wylanie Ducha, "Teologia i Człowiek," Półrocznik Wydziału Teologicznego UMK 2017, no. 2, pg. 38. 
Pastoral theology

neophyte receives the spirit, which is life (Romans 8:6), meaning the Holy Spirit, who is the Spirit of Christ. Paul goes on to describe the gift of the Holy Spirit conferred in baptism as the seal that impresses holiness and belonging to the People of God upon the baptized ( 2 Cor 1:21; Eph 1:13, 4:30). ${ }^{9}$

Baptism is the sacrament that purifies the baptized person from original sin; brings about his spiritual rebirth; and welcomes him into and unites him with the Church. Through his reception of the sacrament of Baptism, the baptized person becomes a Christian and can receive the other sacraments. Because of the solemn way in which it is instituted as well as its constitutive character, Baptism is considered the fundamental sacrament and counted among the major (or main) sacraments.

The sacrament of Confirmation is closely linked with Baptism. Confirmation gives man new life by situating his life in the power of the Holy Spirit. The sacrament of Confirmation confers Christian maturity on the recipient..$^{10}$ The Code of Canon Law (CCL) states: "Every baptized person not yet confirmed and only such a person is capable of receiving confirmation" (Can. $889 \S 1$ ). The CCL also explains that the "sacrament of confirmation is to be conferred on the faithful at about the age of discretion unless the conference of bishops has determined another age, or there is danger of death, or in the judgment of the minister a grave cause suggests otherwise" (Can. 891). Generally, the sacrament of Confirmation should be conferred on adolescents between the ages of 15-16 years old. Youth enter into puberty at this age; they being to think about their future; and they experience the problems of life and learn what they believe. This, in turn, enables them to more freely and consciously choose to be confirmed; understand the importance of the gifts of the Holy Spirit in the formation of their personalities; and more effectively take on the obligation to witness to their faith. ${ }^{11}$

In our present age, the issue of not having received the sacrament of Confirmation for a variety of reasons arises during preparation for marriage and family life. In such a situation, the CCL teaches that, "Catholics who have not yet received the sacrament of confirmation

9

The New Testament speaks of Paul, Peter, and John's three different approaches to baptism. See Ibid, col. 354 .

10

11

B. Snela, Bierzmowanie, EK II, col. 547.

Instrukcja przygotowania młodzieży do sakramentu bierzmowania (16.01.1975).

Warsaw 1975, no. 3. http://www.kkbids.episkopat.pl/?id=179 (Accessed: 03.02.2018). 
are to receive it before they are admitted to marriage if it can be done without grave inconvenience" (Can. 1065). It is advisable for the faithful to receive the sacrament of Confirmation in order to fully lead a spiritual life. Confirmation obliges those who are confirmed "more firmly to be witnesses of Christ by word and deed and to spread and defend the faith" (Can. 879).

The Eucharist is the third sacrament of Christian initiation. The Eucharist is the greatest good as well as the center of Christian life. The Eucharist is a mystery, in which the bread and wine are transformed into the Lord's Body and the Blood. Christ instituted the Eucharist during the Last Supper when he blessed the bread, broke it, and gave it to his disciples, saying: "Take it; this is my body"' (Mk 14:22). Then he took the cup, gave thanks, and gave it to his disciples to drink, saying: "This is my blood of the covenant, which will be shed for many" (Mk 14:24). ${ }^{12}$ The Eucharist is considered God's Paschal Feast and New Covenant not only with man, but also with the whole universe. Freed from the bonds of time and space, the Eucharist is the anticipation of the heavenly banquet. On the one hand, the Eucharist is thanksgiving for the gift God gives in the community of the Church, and, on the other hand, it is also that which constitutes the Church so that, within the Church, God and man can be reconciled with each other by the most perfect love. ${ }^{13}$

\section{The Importance of the Sacraments of Christian Initiation in Preparing Couples for Married and Family Life}

Christian initiation plays an essential role in preparing individuals for married and family life not by presenting information, but through the activities and dialogue of those who participate in it. ${ }^{14}$ Initiation takes place on two levels. The first level involves the person and his deep intimacy with Christ, such that the person who is preparing for marriage and family life experiences change in his encounter with a new life and new reality. The second dimension concerns the community, which is necessary condition and aim for initiation. This

12 F. Gryglewicz, Eucharystia, EK IV, col. 1239-1240.

13 See Redemptor Hominis 20; J. Tyrawa, Eucharystia - dzieje problematyki, EK IV, col. 1247; A. Żurek, Mysterium Passionis - Corpus et Sanguis Christi-Communio, Eucharystia sakramentem wtajemniczenia chrześcijańskiego w Kościele tacińskim czwartego i poczatku piatego wieku. Katowice 2012, pg. 34 . 
Pastoral theology

relationship occurs between the community and the one who receives a particular sacrament, and it demonstrates that faith pertains not only to the individuals who profess it, but also to the community that it both creates and necessitates. ${ }^{15}$

In his Apostolic Exhortation Catechesi Tradendae, Pope John Paul II speaks of the relationship that exists between the profession of faith and the Church in the following way:

A person who has given adherence to Jesus Christ by faith and is endeavoring to consolidate that faith by catechesis needs to live in communion with those who have taken the same step" (24). Additionally, in his encyclical Redemptoris Missio, Pope John Paul II emphasizes that "convert[s] [...] would be greatly disappointed if, having entered the ecclesial community, they were to find a life lacking fervor and without signs of renewal!" (47). Initiation is, therefore, an ongoing process ( $\mathrm{Lu}$ men Gentium 11). ${ }^{16}$

During marriage preparation, the Church must teach engaged couples about the relationship that exists between the sacrament of marriage for which they are preparing, and the sacrament of baptism, which is integrated into the sacramental economy by which faithful Christians live. Pope Francis' Apostolic Exhortation Amoris Laetitia refers to this reality when it states that "By their baptismal consecration, they were enabled to join in the marriage as the Lord's ministers and thus to respond to God's call" (75). In the sacrament of marriage, both Baptism and Confirmation are intimately connected with the mystery of God's love. Baptism is a sign of God's love for man, and through marriage, the faithful participate in God's creative work and cooperate with the Creator and Savior's love. In this way, marital love is incorporated into God's love, which embraces every human person in the sacrament of holy Baptism. ${ }^{17}$

The sacrament of Confirmation is the second sacrament of Christian initiation that plays an important role in preparing individuals for married and family life. In parish practice, however, it is clear that individuals know very little about this sacrament and rarely receive it. In addition, many of the faithful are unaware of the Christian mission

\footnotetext{
$15 \quad$ H. Łuczak, Wspólnota wiary, Wroclaw 1986, pg. 42.

16 See H. Bourgerois, B. Sesboüè, P. Tihon, Znaki zbawienia, Cracow 2001, pg. $222 \mathrm{nn}$.

17 J. Bajda, Elementy powołania matżenstwa $i$ rodziny, in Teologia matżeństwa i rodziny, vol. 1, K. Majdański (ed.), Warsaw 1980, pg. 51.
} 
with which they are entrusted when they receive the sacrament of Confirmation. ${ }^{18}$

The sacrament of Confirmation, just like the sacraments of baptism and the Eucharist, has a pneumatological dimension. This means that the sense and effects of Confirmation arise from one and the same gift of the Holy Spirit-from the communion that exists between the community and Christ in the Holy Spirit. Confirmation should influence the life of the one who receives it by enabling the individual to strengthen and develop his personal spiritual life. Confirmation should also strengthen the bond that already exists between the baptized and the Church by establishing a more complete union between man and Christ. ${ }^{19}$

Some theologians assume that Confirmation is not necessary for salvation. As a community, however, the Church needs the sacrament of Confirmation. The grace of a new life in the Holy Spirit that the believer receives through the sacrament of Confirmation is also the grace of receiving the world through God in order to change it. Confirmation fulfills another mission-namely, it makes it possible for the one who receives it to transform the world through the help of the various charisms that the Holy Spirit bestows in this sacrament. ${ }^{20}$

The Eucharist is the highest act of the worship of God through Christ's mediation. It also points to the biblical image of the Church as the People of God who participate in the salvific functions of the Most High Priest, Christ (see Sacrosanctum Concilium 9-17, 19). In his Apostolic Exhortation Amoris Laetitia, Pope Francis points out "the importance of family spirituality, prayer and participation in the Sunday Eucharist" (223). The Eucharist incorporates man and his family into one body, the Church. Pope Francis teaches that those "who approach the Body and Blood of Christ may not wound that same Body by creating scandalous distinctions and divisions among its members" (186).

18 The Commission of the Archdiocese of Cracow's Liturgical Instruction. Sakrament Bierzmowania w duszpasterstwie, "Notificationes e Curia Metropolitana Cracoviensi" 1976, nos. 6-8, pg. 143-153.

19 Z. Narecki, Duszpasterstwo zwyczajne w parafii a urzeczywistnianie Kościoła, Lublin 2001, pg. 330.

20 The pastoral problem with which the Church is struggling today is the age at which the sacrament of Confirmation should be conferred and the mature formation of the Christian receiving the sacrament. Although Christian maturity is not identical with a person's psychophysical maturity, age does matter here. The Church suggests that Confirmation should be conferred on those who have reached Christian maturity so that the fullness of the Holy Spirit can take root in them and impel them to take on responsibility and fulfill functions in the Church. See. Snela, Bierzmowanie, EK II, col. 549. 
Pastoral theology

Therefore, the celebration of the Eucharist should serve as a constant call to the faithful to open themselves to greater communion with those who are rejected by society. Receiving the sacrament of Eucharistic love should make Christians one body.

In his encyclical Deus Caritas Est, Pope Benedict XVI teaches that the faithful should remember that the

\begin{abstract}
'mysticism' of the sacrament [of the Eucharist] has a social character" (14). Families who receive the Eucharist are more open to apostolic activities by, for example, getting involved in helping the needy. ${ }^{21} \mathrm{In}$ addition, future spouses who seek the proper way to develop a Eucharistic spirituality are able to perceive the deep connection between married life and the Eucharist. In this way, the Eucharist becomes the strength and the inspiration to live the marriage covenant as a 'domestic church. ${ }^{22}$
\end{abstract}

The Eucharist expresses the most complete attitude of faith and love, which becomes the source and goal of the Church's salvific activities. A Christian sacramental lifestyle arises from worship, and the Eucharist leads the baptized person into fullness of his initiation, which began at baptism. In the Eucharist, everything that is human undergoes a particular transformation and elevation because the Eucharist is Christ Himself, who, through his Body and Blood, "give life to men who are thus invited and encouraged to offer themselves, their labors and all created things" (Presbyterorum Ordinis 5).

\title{
The Sacraments of Initiation and Family Life
}

Christian initiation gives a person who is preparing for marriage and family life the opportunity to form the proper Christian attitudes in oneself and live well within a the family community. It also creates an opportunity for the person to understand living a Christian way of life not as one of many projects, but rather as the most interesting and rational proposition. Christian initiation also extends beyond the dimensions of earthly life and concerns forming man in the "image and likeness of God." This approach to life, which is often strewn with difficulties, is necessary.

\footnotetext{
$21 \quad$ See Amoris Laetitia 186.

22 See Ibid, 318. Por. J. Bajda, Bosko-ludzki charakter Kościoła domowego, in Rodzinajako Kościót domowy, A. Tomkiewicz, W. Wieczorek (ed.), Lublin 2010, pgs. 56-59; K. Więsyk, K. Wojaczek, Urzeczywistnianie się Kościoła w małżeństwie $i$ rodzinie, in Małżeństwo $i$ rodzina $w$ świetle nauki Kościoła i wspótczesnej teologii, A.L. Szafrański (ed.), Lublin 1985, pgs. 232-235.
} 
A crisis of faith can bring can cause an individual to realize that the vocation to a marriage and family life must be lived in accordance with God's will. An individual who has received the Christian sacraments of initiation may have never truly encountered Christ in his own life. As a result, such an individual does not understand what the Christian community is and, subsequently, does not feel like a member of the Church in which he or she has been introduced by the virtue of the sacrament of baptism. Those who are preparing for marriage Pastoral and family life and experiencing crises of faith most often grew up being exposed to imperfect examples of marriage and family life. For Christians, Christ is the best model for marriage and family life. This is why those who follow Christ and lead and introduce people to the sacraments of Christian initiation play such an important role. For, through their behavior, they serve as role models. It is for this reason that every Christian should live according to the teachings of the Church and sanctified by the grace of Christ, from whom every sacrament draws its power (Sacrosanctum Concilium 61). In this way, different events that occur in family life can become a means of an individual's sanctification and worship of God.

For parents, the baptism of a child is often an occasion that makes it possible for them to experience the sacraments of Christian initiation. Just like every other sacrament, Baptism is a sacrament of faith. He who believes in Jesus Christ as Savior and desires to live according to His Gospel and the teachings of the Church can receive Baptism. ${ }^{23}$ Celebrations of the birth of a child may become an opportunity for families witnessing the baptism of a child in the parish to better understand the deep bonds that the sacrament of baptism creates between the child and God as well as the child and the Christian community. When presenting their child for the sacrament of Baptism, parents should be aware that they must create in their home a stable, sure, and natural atmosphere where the flame of faith flourishes and the newly-baptized child's conscience is formed and deepened. ${ }^{24}$

When engaged couples enter into the sacrament of Marriage, they express their willingness to be open to new life and their obligation to raise children according to the teachings of the Catholic Church. Therefore, the baptism of a child should be an occasion for parents to

23 C. Krakowiak, Udział rodziców $w$ przygotowaniu do sakramentów inicjacji chrześcijańskiej, in W poszukiwaniu katechezy rodziców. Studium teoretyczno-empiryczne, J. Stala, E. Osewska (eds.), Tarnow 2007, pgs. 164-168.

24 J. Charytański, Chrzest a życie chrześcijańskie. Studium katechetyczne, Warsaw 1970, pg. 56; M.E. Jorge, Chrzest dla mojego dziecka, trans. W. Dzieża, Pelplin 2016. 
Pastoral theology

deepen their faith. In situations where parents live in civil marriages, their parish priest or deacon should encourage them to enter into a sacramental marriage. ${ }^{25}$ Parents who cannot enter into a sacramental marriage should be shown particular pastoral care; they should be encouraged to pray together as a family, raise their children in the Christian faith, and practice penance and acts of mercy. ${ }^{26}$

The sacrament of Confirmation is an important sacrament of Christian initiation. Even before an individual receives this sacrament, the Church emphasizes how it is important to prepare candidates to receive Confirmation by forming in them the proper dispositions and ensuring that they meet the requirements of having reached the proper age and attained the necessary moral qualifications. The goal of Confirmation is to prepare Christians who are preparing to receive the sacrament to be involved in the Church, to share responsibility for their fate and the fate of the parishes to which they belong, and to get involved in activities that are proper to their state and abilities in life. ${ }^{27}$ Good knowledge of and familiarity with the structures and theology of Christian initiation will help Christians find the right way, especially when they are confronted with other propositions. Those who are involved in Confirmation preparation should strive to interest these Christians in God the Creator and the saving work of His Son, Jesus Christ, so that these individuals can become open to the working of the Holy Spirit. This process should occur naturally and gradually, rather than mechanically and suddenly. In addition, care should be taken to ensure that individuals who are preparing for marriage and family life are able to systematically discover God's mysteries, since this is a task that lasts a lifetime.

An attitude of authentic faith helps individuals understand the sacrament of Confirmation. Youth who are raised in a spirit of authentic faith easily and courageously witnesses to Christ in their lives. Confirmation

${ }_{25} \quad$ K. Dullak, Chrzest dzieci rodziców żyjacych bez sakramentu matżeństwa, "Colloquia Theologica Ottoniana," 2012, no. 2, pg. 83.

26 Pierwszy Synod Diecezji Rzeszowskiej 2001-2004, Statut 251, Rzeszów 2004, pg. 134.

27 Preparation to receive the sacrament of Confirmation takes place in three stages: long-term, short-term, and immediate. During the first stage, the basic aim is to include and properly prepare families who are raising their children in the faith through their attitudes and behaviors. The second stage of preparation includes doctrinal and metholodogical formation provided through conferences. The third stage of preparation involves participating in meetings with other families, witnesses, and the entire parish community. See Instrukcja dotyczaca Sakramentu Bierzmowania. Przyjęta na 146 Zebraniu Konferencji Episkopatu Polski, "Częstochowskie Wiadomości Diecezjalne” 1975, nos. 9-10, pgs. 194-198. 
is the sacrament that signifies Christian maturity; therefore, individuals who have received this sacrament should live it out in their daily lives by courageously resisting temptations to sin and by boldly proclaiming how one's entire life belongs to Christ. ${ }^{28}$

The Eucharist also plays an important role in preparing couples to for married and family life. Introducing an engaged couple to the liturgy of the sacrament of Marriage during their marriage preparation will help them discover the importance of their Eucharistic Communion with each other on their wedding day and with the those who will participate in the celebration of their marriage. The Eucharist is the main source of love, and it is because of this sacrament that the faithful can enter into the community of love with God and with each other. For this reason, the celebration of the Eucharist should be treated as a natural and essential part of the marriage liturgy that takes place in the context of the celebration of Holy Mass. ${ }^{29}$ The Eucharist gives birth to and builds up the Church, which exists thanks to the Eucharist ${ }^{30} \mathrm{It}$ is the sacrament of the unity between Christ and his Church and the sacrament that strengthens the unity and love of the spouses. ${ }^{31}$

The Eucharist should be the center of a Christian family's life. However, whether or not this occurs depends largely on parents. Parents are primarily responsible for introducing children into the mystery of the Eucharist. They can be particularly active in preparing their children to receive First Communion. To this end, parents are obligated to attend catechesis with their children so that they can properly dialogue with their children at home about what the child learns during catechesis. Children, in turn, should be instilled with a sense of the solemnity and importance of their First Communion, which will enable them to fully participate in the Mass by receiving Jesus in the Eucharist. During the celebration of a child's First Holy Communion, parents are able to renew the promises that they made during the child's baptism. For this reason, it is important for the parents and godparents to remind the child about the obligations that arise from the sacrament of Baptism. When a child receives his or her First Holy

28

See K. Misiaszek, Bierzmowanie: sakramentem dojrzałości czy sakramentem ksztattowania dojrzałości? "Studia Koszalińsko-Kołobrzeskie”, no. 24 (2017), pgs. 257-264.

29

Obrzędy sakramentu matżeństwa dostosowane do zwyczajów diecezji polskich, 35 .

See Ecclesia de Eucharistia 1, 21-25.

See Gratissimam Sane 19; Eucharystia a matżeństwo, edited by Centralna Diakonia Domowego Kościoła, Cracow 2013, pg. 16. 
Communion, both the parents and the child are able to unite their family's difficulties and sacrifices with the sacrifice of Christ during the Holy Mass. When families participate in Holy Mass together, then this strengthens family bonds even more. ${ }^{32}$

Participation in Sunday Mass plays an important role in the religious upbringing and education of a child, which parents promise to provide. In a Christian family, religious education should be connected with the Holy Mass (DD 3). Sunday is a day that unites the family around the Person of Jesus Christ who has conquered everything. For the Christian family, participating in the Sunday celebration of the Eucharist is the family's main cause for joy and communal celebration, communal prayer around a common table (the altar), and a communal offering of time. In a Christian family, keeping Sunday holy is the context in which one learns how to live correctly, share in the faith of a community, and learn lessons in dynamic love. It is a duty for Christians, therefore, to personally ensure that Sunday is a day that is spent with family. ${ }^{33}$

$$
\text { *** } *
$$

An individual can more easily find the appropriate life path to follow when he knows the structure and theology of Christian initiation. By having a good knowledge of and being familiar with the sacraments of Christian initiation and by properly experiencing these sacraments, an individual can develop a deeper interest in God the Creator and the saving work of His Son Jesus Christ and become more open to the working of the Holy Spirit, particularly when life presents other options and paths that lead away from Christ. It is important that this process occur naturally and gradually, rather than mechanically and suddenly. Those involved in preparing individuals for marriage and family life should take care to ensure that these individuals are able to systematically discover God's mysteries anew throughout their entire lives.

\footnotetext{
32 "No Christian community, however, is built up unless it has its basis and center in the celebration of the most Holy Eucharist; from this, therefore, all education to the spirit of community must take its origin" (Presbyterorum Ordinis 6). 


\section{ROLA SAKRAMENTÓW WTAJEMNICZENIA CHRZEŚCIJAŃSKIEGO W PRZYGOTOWANIU DO ŻYCIA MAŁŻEŃSKIEGO I RODZINNEGO}

We współczesnych czasach zauważa się, że osoby przygotowujące się do życia małżeńskiego i rodzinnego nie otrzymały wystarczającej formacji w domu rodzinnym co powinny gwarantować sakramenty wtajemniczenia chrześcijańskiego. Sakramenty chrztu, bierzmowania i Eucharystii wszczepiają człowieka w Chrystusa i powodują, że przyjmujący je staje się nowym stworzeniem i pełnoprawnym członkiem Kościoła. Rolą Kościoła jest ukazywanie związku, jaki istnieje między sakramentem małżeństwa, do którego człowiek wierzący się przygotowuje, a sakramentami wtajemniczenia chrześcijańskiego. Wpisują się one integralnie w ekonomię sakramentalną, którą żyje wierzący i praktykujący chrześcijanin. Przyszli małżonkowie poszukując właściwej drogi rozwoju wspólnego życia, mogą dostrzec głębokie więzi między życiem małżeńskim a sakramentami wtajemniczenia. Zdarzają się jednak sytuacje, że osoby, które przyjęły sakramenty inicjacji chrześcijańskiej nie spotkały w swoim życiu Chrystusa. Nie rozumieją czym jest chrześcijańska wspólnota i nie czują się w pełni członkami Kościoła, do którego zostali na mocy sakramentów wprowadzeni. Dlatego należy szukać rozwiązań, które pomogą w tym, aby ich życie małżeńsko-rodzinne zostało przeniknięte obecnością Chrystusa.

Słowa kluczowe: inicjacja, wtajemniczenie chrześcijańskie, chrzest, bierzmowanie, Eucharystia, przygotowanie do życia małżeńskiego i rodzinnego.

\section{Bibliography:}

1. Bajda J., Elementy powołania matżeństwa i rodziny, in Teologia matżeństwa i rodziny, Vol. 1, K. Majdański (ed.), Warsaw 1980, pgs. 31-89.

2. Bajda J., Bosko-ludzki charakter Kościoła domowego, in Rodzina jako Kościót domowy, A. Tomkiewicz, W. Wieczorek (ed.), Lublin 2010, pgs. 55-66.

3. Bourgerois H., Sesboüè B., Tihon P., Znaki zbawienia, Cracow 2001.

4. Charytański J., Chrzest a życie chrześcijańskie. Studium katechetyczne, Warsaw 1970.

5. Dullak K., Chrzest dzieci rodziców ̇̇yjacych bez sakramentu matżeństwa, "Colloquia Theologica Ottoniana," 2012, no. 2, pgs. 81-91.

6. Instrukcja dotyczaca Sakramentu Bierzmowania. Przyjęta na 146 Zebraniu Konferencji Episkopatu Polski, “Częstochowskie Wiadomości Diecezjalne" 1975, nos. 9-10, pgs. 194-198.

7. Jastrzębski A., Katechumenat jako droga do dojrzałości chrześcijańskiej na kolejnych etapach rozwoju człowieka, „Wrocławski Przegląd Teologiczny”, R. 22, no. 2 (2014), pgs. 203-214.

8. Jorge M.E., Chrzest dla mojego dziecka, trans. W. Dzieża, Pelplin 2016.

9. Krakowiak Cz., Katecheza chrzcielna w Kościele posoborowym, Lublin 2003. 
10. Krakowiak Cz., Inicjacja chrześcijańska, in Leksykon Teologii Pastoralnej, R. Kamiński, W. Przygoda, M. Fiałkowski (ed.), Lublin 2006, pgs. 298-300.

11. Kunka S., Sakrament bierzmowania a wylanie Ducha, "Teologia i Człowiek," Półrocznik Wydziału Teologicznego UMK 2017, no. 2, pgs. 33-57.

12. Łuczak H., Wspólnota wiary, Wroclaw 1986.

13. Misiaszek K., Bierzmowanie: sakramentem dojrzałości czy sakramentem ksztattowania dojrzatości? "Studia Koszalińsko-Kołobrzeskie," no. 24 (2017), pgs. 257-264.

14. Murawski R., Wtajemniczenie chrześcijańskie w pierwotnym Kościele, in Funkcja inicjacyjna katechezy w Kościele wspótczesnym, K. Kantowski (ed.), Szczecin 2007, pgs. 33-52.

15. Nadolski B., Eucharystia: dar Boga dla życia świata, Poznan 2008.

16. Narecki Z, Duszpasterstwo zwyczajne $w$ parafii a urzeczywistnianie Kościoła, Lublin 2001, pgs. 328-336.

17. Tomasik P. (ed.), Rodzina-szkoła-Kościót. Korelacja i dialog, Warsaw 2003.

18. Tomasik P., Katecheza i inicjacja w ujęciu dokumentów Kościoła, in Funkcja inicjacyjna katechezy w Kościele wspótczesnym, K. Kantowski (ed.), Szczecin 2007, pgs. 81-95.

19. Szpet J., Inicjacyjna funkcja katechezy, "Horyzonty Wiary" 1996, no. 3, pgs. 55-72.

20. Więsyk K., Wojaczek K., Urzeczywistnianie sie Kościoła $w$ matżeństwie i rodzinie, in Matżeństwo i rodzina w świetle nauki Kościoła i wspótczesnej teologii, A. L. Szafrański (ed.), Lublin 1985, pgs. 201-238. 